\title{
Managed Alcohol Programs - reducing social and injury harm, but what about long-term health harm?
}

Robin Room

Centre for Alcohol Policy Research, La Trobe University, Melbourne, Australia; Centre for Social Research on Alcohol and Drugs, Department of Public Health, Stockholm University, Stockholm, Sweden

Housing for homeless heavy drinkers (HHD), mostly men, is not a new idea. Private provision of it has a lengthy history. The single room-occupancy hotels in "skid rows" - seedy central-city neighbourhoods - have a history dating back to the $19^{\text {th }}$ century in the United States, for instance Bogue et al [1]. The modest requirements of the men for accommodation - a cubicle with fireproof walls enclosing a bed, with chicken-wire over its top - and the cheap real estate in a depressed area of town meant that such a hotel could be modestly profitable. Public provision, whether with government or charitable support, was already in evidence early in the $20^{\text {th }}$ century [2], and became common in many industrialising countries.

Providing housing for the homeless, whatever their habits, can have a variety of charitable motivations. For many, it can be fulfilment of a religious duty: "I was a stranger, and you took me in" (Matthew 25:35). In a secular version, making sure that everyone is housed can be seen as a solidarity principle of the welfare state. In settler societies such as Canada or Australia, groups of Indigenous men are often prominent among the street drinkers, and politicians often feel an inchoate special duty to provide for their care. Particularly where winters are cold, as in Canada, providing shelter can be a matter of survival. With heavy drinkers, there is also the potential for reform: perhaps the welcome and the offer of shelter will move the drinker to do something about his habit, to reform himself. Medicine, psychology, religion or Twelve Step principles may be offered to help him along this path.

On the other hand, HHDs can be troublesome. The fireproof walls and chicken-wire of the single room-occupancy hotels were protective measures against the bad and uncontrolled behaviour common on skid row. HHDs are also frequently viewed as unsightly. Many are part of an active subculture [3], often gathering in public spaces, and thereby impairing the amenity of the space for the straitlaced and scaring away potential customers of local merchants. As "urban renewal" took hold in the US in the 1950s and after, skid row's inhabitants were seen as occupying potentially valuable urban space; sociologists employed to smooth the way of redevelopment joked that the programs might more precisely be called "Skid Row removal". And HHDs are costly for the modern state: discouraging them by active policing results in costly incarcerations, and they are heavily represented among the "frequent flyers" as regular customers of hospital emergency departments and other expensive public facilities.

There are thus often a mixture of motives behind official and charitable efforts to offer free housing and other benefits for HHDs. The offer is frequently seen as one side of an implicit or explicit bargain, with something expected in return. At a minimum, the expectations when housing is

This is the author manuscript accepted for publication and has undergone full peer review but has not been through the copyediting, typesetting, pagination and proofreading process, which may lead to differences between this version and the Version of Record. Please cite this article as doi: $10.1111 /$ dar.12690 
provided will be in terms of behaviour while on the premises. Those offered the housing are commonly well aware of the bargain's terms; the informal "telegraph" within subcultures of street drinkers is usually strong. With an overnight bed at a religious city mission, for instance, you get a meal, but in return you have to sit through a religious service [4]. The HHDs often walk away from an offer where the conditions are seen as not worth it.

Requirements of abstinence from alcohol, or of no alcohol within the housing, have been commonplace. Such requirements may be motivated by a desire to avoid mess, trouble and disturbance of other residents. In the past, the requirements were often motivated also by temperance sentiments, and in the present by strong beliefs that abstinence is a requisite for recovery from alcoholism, which HHDs are seen as having. But in the last few years there been new moves in several countries towards housing where drinking is permitted on premises. For instance, Shoreline in Cardiff, Wales began providing "wet housing for heavy drinkers" in 1996 [5, pp. 16-17]; by 2005, a "Housing First" initiative in Seattle was admitting chronic homeless individuals and allowing them to drink in their rooms [6]. Such moves are often controversial; it is argued that providing resources which make it possible for HHDs to access alcohol makes the state an "enabler" of the addiction [7, p. 39]. In Canada, too, Pauly et al. [8] mention "potential controversy" and backlash which has meant that some MAPs operate "under the radar". "Wet housing" and other moves away from an abstinence standard can be seen as broadly guided by a harm reduction approach, as opposed to the abstinence approach long dominant in north American alcohol programs. But it emerges there are many nuances to harm reduction; Pauly et al. [8] report an interesting range of program goals and philosophies in the MAPs.

The Canadian MAPs push the issue one step further than wet housing, in that governmental resources are being used to actually provide the alcohol, sometimes purchased by the MAP and sometimes paid for from residents' welfare payments. This is not totally unprecedented; for instance, in the early 1970s a small beer ration was provided daily in New York City's residential centre in upstate New York to the HHDs brought there from the city's skid row [9]. But the amounts of alcohol provided in the Canadian MAPs are much greater than in earlier precedents. In a majority of the MAPs, the doses are up to a little more than two bottles of wine a day, and in a minority of programs they may be as high as 3-4 bottles a day [8]. Added to this consumption often is alcohol obtained "outside" by the program participants [10]. A comparison study with HHDs not in MAPs [11] suggests that the main effect of entering a MAP in the medium term is not to alter the cumulative volume of drinking but rather to change its patterning: longer-term residents in MAPS drink more evenly day in and day out, while those outside drink on fewer days but larger amounts on a drinking day. The MAP residents report fewer social and safety problems related to their drinking in the shorter run; the more evenly spread pattern of consumption thus seems to reduce the social problems associated with HHDs.

But the amount of alcohol consumed by MAP residents carries a high risk to their health in the longer term. As Pauly et al. [8] note, alcohol has "many more adverse health and safety effects" than heroin, the drug which has been the focus of the modern harm reduction movement. Unlike tobacco smoking or heroin injection, alcohol consumption cannot be made substantially safer in terms of 
cumulative health effects by changing the mode of use of the psychoactive substance. It is thus appropriate for Pauly et al. [8] to argue for preventive steps concerning liver disease - and such steps are also needed for other chronic illnesses associated with chronic heavy drinking. Beyond that, there is also a strong argument for continuing efforts to persuade MAP residents to cut down their alcohol consumption. To fit within the MAP philosophy, these efforts will need to respect the drinker's autonomy and avoid coercion. They might, for instance, include suggestions to change to less lethal psychoactive substances than alcohol, for instance by vaping or eating cannabis products as they become legal in Canada. 


\section{REFERENCES}

1. Bogue DJ. Skid Row in American Cities. Chicago: Community and Family Study Center, University of Chicago, 1963.

2. Rice SA. The failure of the municipal lodging house. National Civic Review 1922;11:358-62.

3. Wiseman JP. Stations of the Lost: The Treatment of Skid Row Alcoholics. Englewood Cliffs, NJ: Prentice-Hall, 1970.

4. Bibby RW, Mauss AL. Skidders and their servants: variable goals and functions of the Skid Road rescue mission. J Sci Study Relig 1974;13:421-36.

5. Byrne S, Everitt G, McKeown S. Good Practice Report: New Directions, vol. 2. London: Shelter, 2008. Available from:

http://england.shelter.org.uk/_data/assets/pdf_file/0008/57770/New_directions_in_street_ homelessness_Vol_Two.pdf

6. Larimer ME, Malone DK, Garner MD, Atkins DC, Burlingham B, Lonczak HS, Tanzer K, Ginzler J, Clifasefi SL, Hobson WG, Marlatt GA. Health care and public service use and costs before and after provision of housing for chronically homeless persons with severe alcohol problems. JAMA 2009;301:1349-57.

7. Hunt SR, Baumohl J. Drink, drugs and disability: An introduction to the controversy. Contemporary Drug Problems 2003;30: 9-76.

8. Pauly B, Vallance K, Wettlaufer A, Chow C, Brown R, Evans J, Gray E, Krysowaty B, Ivins A, Schiff R, Stockwell T. Community managed alcohol programs in Canada: Overview of key dimensions and implementation. Drug Alcohol Rev 2018 [In press].

9. Bahr HM, Caplow T. (1973). Old Men Drunk and Sober. New York: New York University Press.

10. Chow C, Wettlaufer A, Zhao J, Stockwell T, Pauly B, Vallance K. Counting the cold ones: A comparison of methods measuring total alcohol consumption of managed alcohol program participants. Drug Alcohol Rev 2017 [Epub ahead of print].

11. Stockwell T, Pauly B, Chow C, Erickson RA, Krysowaty B, Roemer A, Vallance K, Wettlaufer AA, Zhao J. Does managing the consumption of people with severe alcohol dependence reduce harm? A comparison of participants in six Canadian managed alcohol programs with locally recruited controls. Drug Alcohol Rev 2017 [Epub ahead of print].

This article is protected by copyright. All rights reserved. 


\section{University Library}

\section{- M M I N E R VA A gateway to Melbourne's research publications}

Minerva Access is the Institutional Repository of The University of Melbourne

Author/s:

Room, R

Title:

Managed alcohol programs: Reducing social and injury harm, but what about long-term health harm?

\section{Date:}

2018-04-01

\section{Citation:}

Room, R. (2018). Managed alcohol programs: Reducing social and injury harm, but what about long-term health harm?. DRUG AND ALCOHOL REVIEW, 37, pp.S197-S198. https:// doi.org/10.1111/dar.12690.

Persistent Link:

http://hdl.handle.net/11343/283741 